mł. bryg. dr inż. Joanna Rakowska ${ }^{1}$

mgr Katarzyna Radwan ${ }^{1}$

mgr Bożenna Porycka ${ }^{1}$

Przyjęty/Accepted/Принята: 03.08.2015;

Zrecenzowany/Reviewed/Рецензирована: 18.08.2015;

Opublikowany/Published/Опубликована: 30.09.2015;

\title{
Metody oceny środków pianotwórczych do gaszenia pożarów w portach morskich ${ }^{2}$
}

\author{
Methods for Evaluating Firefighting Foam Used at Seaports
}

Методы оценки пенообразующих средств для тушения пожаров в морских портах

\begin{abstract}
ABSTRAKT
Cel: Podczas akcji gaśniczych w portach morskich lub na statkach pianotwórcze środki gaśnicze stosuje się zazwyczaj z wodą morską. Skład wody morskiej znacznie różni się od składu wody wodociągowej. Wody słone zawierają znaczne ilości soli mineralnych, które mogą powodować niszczenie pian gaśniczych, zmniejszając skuteczność gaśniczą, co ma istotny wpływ na powodzenie akcji ratowniczej. Z uwagi na to środki pianotwórcze przeznaczone do stosowania z wodą morską powinny posiadać podwyższoną odporność na duże stężenie elektrolitów zawartych w wodzie zasolonej. Celem artykułu jest porównanie przydatności metod badania jakości środków pianotwórczych stosowanych do gaszenia pożarów przy użyciu wody zasolonej.

Projekt i metody: W badaniach wykorzystano najczęściej stosowane w Europie metody badań środków pianotwórczych przeznaczonych do stosowania z wodą morską określone w normach PN-EN 1568 cz. 1-4, ISO 7203-1 i ISO 7203-3 w przepisach Międzynarodowej Organizacji Morskiej (IMO). W artykule przedstawiono wyniki badań jakości piany: liczby spienienia i szybkości wykraplania piany oraz skuteczności gaśniczej: czasu gaszenia i czasu nawrotu palenia trzech syntetycznych środków pianotwórczych (środki S1, S2 i S3) i jednego środka fluoroproteinowego (FP 4). Środki S1 i S3 były przeznaczone do stosowania tylko z wodą niezasoloną, natomiast środki S2 i FP4 były przeznaczone do użytkowania z wodą niezasoloną i morską.

Wyniki: Badania, zarówno dla środków przeznaczonych do stosowania z wodą niezasoloną, jak i morską potwierdziły gorszą zdolność pianotwórczą i mniejszą trwałość piany wytworzonej z koncentratów przy zastosowaniu wody zasolonej. Gaszenie pożarów testowych przy zastosowaniu tych samych wydajności piany $(11 \mathrm{l} / \mathrm{min}$ ) jest trudniejsze w przypadku testów określonych w przepisach IMO niż w przypadku innych testów (m. in. ze względu na kształt tacy). Jednak jednoczesne zastosowanie trzech dysz i zwiększenie przez to intensywności podawania piany znacznie poprawia efektywność działań gaśniczych oraz umożliwia szybkie i skuteczne ugaszenie pożaru testowego opisanego w przepisach IMO.

Wnioski: Jakość środków gaśniczych wykorzystywanych podczas akcji gaśniczych ma ogromny wpływ na efektywność działań gaśniczych. W portach morskich szczególnie istotna jest ich odporność na działanie słonej wody. Środek gaśniczy o odpowiedniej jakości, właściwie zastosowany, zwiększa bezpieczeństwo osób oraz umożliwia ograniczenie ekonomicznych i ekologicznych strat pożarowych.
\end{abstract}

Słowa kluczowe: pianotwórcze środki gaśnicze, woda morska, akcje ratowniczo-gaśnicze

Typ artykułu: oryginalny artykuł naukowy

\section{A B S T RACT}

Aim: Fire extinguishing foam is usually combined with sea water during firefighting operations on a ship or at a seaport. The structure of sea water is different from fresh water. Sea water contains large quantities of mineral salts, which may cause the deterioration of extinguishing foam and consequently reduce the effectiveness of firefighting. For this reason foam intended for use in conjunction with sea water should contain a higher resistance to the high concentration of electrolytes contained in salt water. The purpose of this paper is to compare the suitability of testing methods for foam used in firefighting, which is mixed with sea water.

Project and methods: This research project utilised the most commonly used methods in Europe for testing firefighting foam, which is mixed with sea water, specified in standards; PN-EN 1568, ISO 7203-1, ISO 7203-3 and regulations from the International Maritime

\footnotetext{
Centrum Naukowo-Badawcze Ochrony Przeciwpożarowej - Państwowy Instytut Badawczy; / Scientific and Research Centre for Fire Protection - National Research Institute, Poland; jrakowska@cnbop.pl

2 Wkład merytoryczny w powstanie artykułu / Percentage contribution: J. Rakowska - 50\%, K. Radwan - 35\%, B. Porycka - 15\%;
} 
Organisation (IMO). The article reveals results from investigations dealing with foam quality for three synthetic foaming agents (S1, S2 and S3) and one fluoroprotein foam concentrate (FP4). Tests focussed on; foam creation, expansion ratio and drainage velocity, and extinguishing effectiveness. Two foaming agents (S1 and S3) can be mixed with freshwater only. Other agents (S2 and FP4) can be mixed with both, freshwater and sea water.

Results: Tests, of agents intended to be mixed with fresh water as well as those designed for mixing with sea water confirmed an inferior production of foam, with a lower expansion ratio and reduced foam stability, for concentrates formulated with the use of sea water. Achievement of the flow rate identified in IMO regulations was more difficult during tests. However, a simultaneous application of three nozzles and an increase in the delivery intensity significantly increased the effectiveness of extinguishing operations and allowed for quick and successful extinguishing of test fires.

Conclusions: The quality of extinguishing agents used during fire incidents has a large bearing on the effectiveness of firefighting. During operations at sea ports, extinguishing agents' resistance to influences of sea water is of particular importance. An agent, of appropriate quality and suitably applied increases the safety of people and mitigates the economic as well as ecological losses attributable to fires.

Keywords: firefighting foam, sea water, fire and rescue operations

Type of article: original scientific article

\section{АННОТАЦИЯ}

Цель: Во время гасящих работ в морских портах или на морских суднах пенообразующие гасящие средства используются, чаще всего, с морской водой. Состав морской воды значительно отличается от состава водопроводной воды. Соленые воды содержат большое количество минеральных солей, которые могут разрушать гасящую пену, уменьшая её гасящую способность, что имеет существенное влияние на успех спасательной операции. В связи с тем пенообразующие средства, предназначенные для использования с морской водой, должны характеризоваться повышенной устойчивостью к высокой концентрации электролитов, содержащихся в соленой воде. Целью статьи является сравнение пригодности методов тестирования качества пенообразующих средств, используемых для тушения пожаров с помощью соленой воды.

Проект и методы: В исследованиях были использованы наиболее популярные в Европе методы исследований пенообразующих средств, предназначенных для использования с морской водой, указанные в стандартах PN-EN 1568 часть 1-4, ISO 7203-1 и ISO 7203-3, в требованиях Международной Морской Организации (IMO). В статье были представлены результаты исследований качеств пены: её кратности пенообразования и скорости превращения в воду и огнетушащей эффективности: времени тушения и времени рецидива горения трех синтетических пенообразующих средств (средства S1, S2, S3) и одного фторпротеиного (FP 4). Средства S1 и S3 были предназначены для использования только с незасоленной водой, а средства $\mathrm{S} 2$ и $\mathrm{FP} 4$ с незасоленной и морской водой.

Результаты: Исследования как для средств, предназначенных для использования с несоленой водой, так и с морской, подтвердили низкую пенообразующую способность и меньшую стабильность пены, образованной на основе концентратов при помощи солёной воды. Тушение тестовых пожаров при использовании одинаковых значений производительности пены (11 л/м) сложнее для испытаний указанных в требованиях IMO чем при других (между прочим учитывал форму лотка). Однако, одновременное использование трёх насадок и повышение интенсивности подачи пены значительно улучшает эффективность гасящих действий и позволяет быстро и эффективно ликвидировать тестовый пожар, указанный в требованиях IMO. Выводы: Качество гасящих средств, используемых во время гасящих действий, имеет огромное влияние на эффективность тушения пожаров. В морских портах особенно важна их устойчивость к соленой воде. Гасящее средство соответственного качества, которое используется правильно, повышает безопасность людей и позволяет ограничить экономический и экологический ущерб, вызванный пожарами.

Ключевые слова: пенообразующие гасящие средства, морская вода, спасательно-гасящие действия

Вид статьи: оригинальная научная статья

\section{Wprowadzenie}

Port morski to „logistyczny i gospodarczy węzeł w systemie transportu globalnego o silnym morskim charakterze, skupiający funkcjonalnie i przestrzennie różnorodną działalność bezpośrednio lub pośrednio związaną z łańcuchami logistycznymi, których częścią pozostają lądowo-morskie łańcuchy transportowe" [1]. Porty morskie, z uwagi na rolę początkowych i docelowych punktów transportu kolejowego, samochodowego i rzecznego, są dogodnym miejscem lokalizacji wszelkiej działalności gospodarczej, w tym handlowej lub przemysłowej, co powoduje konieczność koncentracji ładunków na ich terytoriach [2].

Takie nagromadzenie różnorodnych materiałów oraz intensywny ruch zwiększa prawdopodobieństwo wystąpienia zdarzeń niebezpiecznych w porcie [3], zarówno na jego obszarze lądowym, jak też w części wodnej. Na skutek takich sytuacji może dochodzić do uwalniania toksycznych substancji, wybuchów, pożarów zagrażających życiu lub zdrowiu ludności oraz powodujących skażenie środowiska [4-6]. Podejmowane akcje ratowniczo-gaśnicze wymagają zastosowania odpowiedniego sprzętu oraz środków, w tym środków gaśniczych.

W ostatnich latach liczba pożarów i wartość strat pożarowych wykazują tendencję rosnącą [7-8]. W celu zapewnienia skutecznych działań ratowniczo-gaśniczych podczas zdarzeń niebezpiecznych należy dysponować odpowiednią liczbą ratowników oraz sprzętem i środkami gaśniczymi. W zależności od rodzaju palącego się materiału powinien zostać zastosowany odpowiedni środek gaśniczy (woda, środek pianotwórczy, proszek gaśniczy lub gaz gaśniczy) oraz dobrany właściwy sprzęt przystosowany do dozowania środka gaśniczego (armatura gaśnicza, pompa) [7-10]. Spośród wymienionych środków gaśniczych najpowszechniej 
stosowana jest woda, nie tylko ze względu na stosunkowo niski koszt użycia, ale również w związku z jej dostępnością oraz właściwościami fizykochemicznymi. Woda stosowana jest nie tylko do bezpośredniego gaszenia pożaru, ale również jako środek chłodzący rozgrzane zbiorniki z płonącymi paliwami ciekłymi lub inne obiekty zagrożone pożarem. Poprzez zastosowanie specjalnych technik podawania oraz odpowiednich środków gaśniczych można dodatkowo zwiększyć efektywność jej działania [9].

Woda stosowana do działań gaśniczych ma różny skład w zależności od źródła jej pochodzenia. Na powierzchni Ziemi jest mniej niż 3\% wody słodkiej, natomiast wody zasolonej jest ponad 97\% [11].

\section{Wody zasolone}

Skład wód zasolonych znacznie różni się od wód wodociągowych. Zasolenie jest to ogólna, wagowa zawartość soli mineralnych rozpuszczonych w wodzie, wyrażona w procentach lub promilach. Wody słodkie zawierają $\mathrm{z}$ reguły węglany, których ogólna zawartość wagowa wynosi około $60 \%$ wszystkich rodzajów soli, natomiast wody morskie zawierają ok. $88 \%$ soli w postaci chlorków. W wodach powierzchniowych duże zasolenie występuje zazwyczaj na obszarach suchych i gorących, gdzie wskutek intensywnego parowania i małej ilości wód opadowych następuje kumulacja, a nawet wytrącanie soli [9].

Najmniejsze zasolenie występuje w strefie okołobiegunowej (25\%), gdzie woda odsala się w procesach zamarzania i topnienia. Natomiast największe zasolenie stwierdzono w Morzu Czerwonym (37-42\%o) ${ }^{3}$. Ze względu na małe zasolenie Bałtyk, jako morze zamknięte, zalicza się do wód słonawych. Średnie zasolenie wód Bałtyku wynosi ok. 7\%o [11]. Na rycinie 1 przedstawiono rozkład zasolenia wód na świecie.
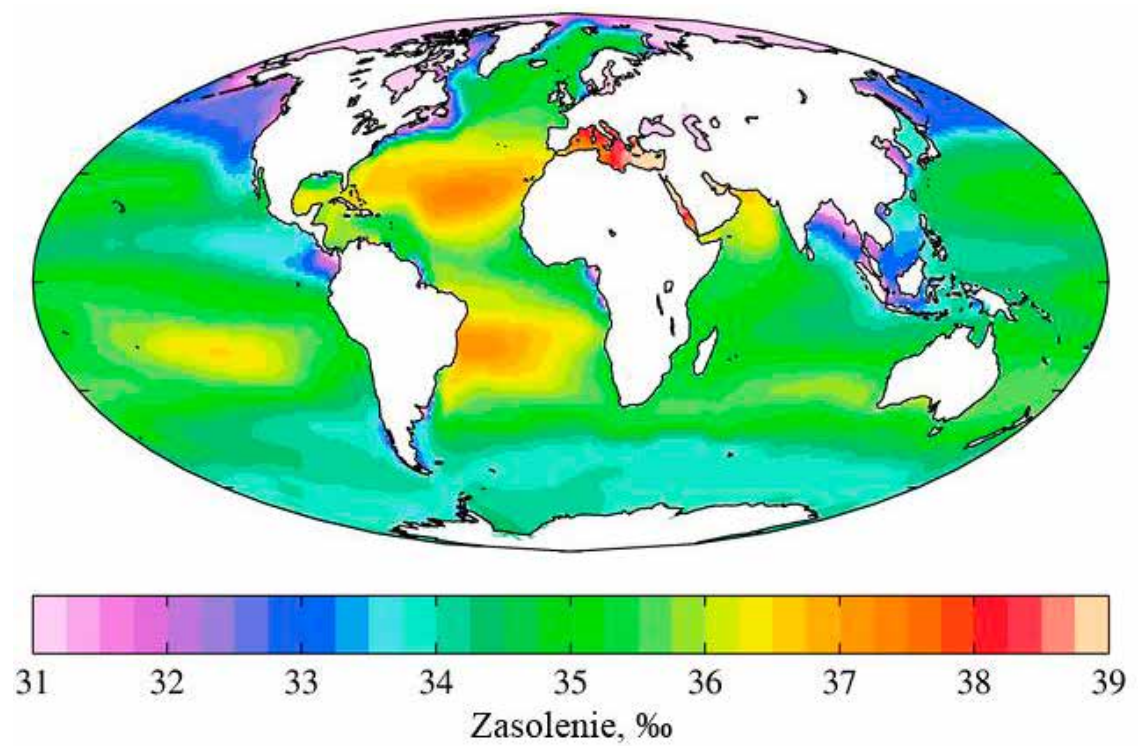

Ryc. 1. Globalna mapa zasolenia [12]

Fig. 1. Global map of salinity [12]

\section{Piany gaśnicze}

Akcje ratowniczo-gaśnicze w portach morskich prowadzone są przeważnie $\mathrm{z}$ użyciem wody morskiej. $\mathrm{Z}$ tego powodu stosowane pianotwórcze środki gaśnicze powinny być odporne na działanie wody zasolonej. Piany gaśnicze wytwarzane są z roztworów wodnych pianotwórczych środków gaśniczych przy zastosowaniu odpowiednich urządzeń. Pianotwórcze środki gaśnicze zależnie od składu chemicznego dzieli się na [13-16]:

- proteinowe $(\mathrm{P})$,

- fluoroproteinowe (FP),

- syntetyczne (S),

- alkoholoodporne środki pianotwórcze (AR),

- tworzące film wodny (AFFF),

- fluoroproteinowe tworzące film wodny (FFFP).

\footnotetext{
3 Nie uwzględniono jezior, w tym M. Martwego i M. Kaspijskiego.
}

Skład pianotwórczych środków gaśniczych determinuje ich właściwości, a w konsekwencji zakres stosowania. Piany gaśnicze są powszechnie używane do ograniczenia rozprzestrzeniania i gaszenia pożarów grupy B (cieczy palnych) oraz do zabezpieczania przed ponownym zapaleniem. Mogą także być stosowane do zapobiegania zapaleniu cieczy palnych oraz do gaszenia pożarów grupy A [9].

Jednymi z czynników wpływających na jakość piany i jej skuteczność gaśniczą, obok takich elementów jak dobór odpowiedniego koncentratu do palącego się materiału, są odpowiednie stężenie środka pianotwórczego w roztworze wodnym, rodzaj sprzętu wytwarzającego pianę, temperatura i jakość wody, w tym stopień jej zasolenia oraz temperatura otoczenia. $W$ wodach zasolonych rozpuszczone są znaczne ilości soli mineralnych; w wysokim stężeniu występują kationy sodu, potasu, magnezu oraz aniony chlorkowe, siarczanowe i węglanowe. Elektrolity zawarte w wodzie zasolonej mogą przyczyniać się jednak do niszczenia pian gaśniczych [9] oraz wpływać na zwiększenie 
ilości osadów w roztworze, powodując zatykanie dysz podających pianę, a tym samym obniżać efektywność akcji ratowniczych. Mogą również zwiększać napięcie powierzchniowe i aktywność związków powierzchniowych, a także reagować ze związkami powierzchniowo czynnymi, głównymi składnikami środków pianotwórczych, co może prowadzić do powstania nowych związków destabilizujących pianę. Środki pianotwórcze przeznaczone do stosowania $\mathrm{z}$ wodą morską, dzięki zawartym $\mathrm{w}$ ich kompozycji odpowiednim składnikom, posiadają podwyższoną odporność na wysokie stężenie elektrolitów zawartych w wodzie zasolonej i dlatego tylko takie produkty powinny być wykorzystywane do gaszenia pożarów z zastosowaniem wody morskiej.

\section{Wybrane metody badania środków pianotwórczych do stosowania $z$ wodą morską}

Oceny przydatności pianotwórczych środków gaśniczych do zastosowania z wodą morską dokonuje się najczęściej w oparciu o badania i wymagania norm PN-EN 1568 cz. 1-4 [13-16], ISO 7203-1 [17] i ISO 7203-3 [18], wymagań zawartych w przepisach Międzynarodowej Organizacji Morskiej (IMO) [19] lub Narodowego Stowarzyszenia Ochrony Przeciwpożarowej USA (NFPA) [20]. W celu określenia jakości piany oraz przydatności do stosowania, w tym $\mathrm{z}$ wodą zasoloną, przeprowadza się badania takich parametrów jak:

- liczba spienienia - stosunek objętości piany do objętości roztworu, z której ją otrzymano [13-19];

- szybkość wykraplania piany - czas wycieku 25\% i 50\% początkowej objętości roztworu z wytworzonej piany [13-19]. Trwałość piany określana jest na podstawie szybkości wyciekania z niej roztworu środka pianotwórczego. Im wolniej następuje proces niszczenia pęcherzyków, tym piana jest trwalsza. Czas, w którym wypłynie $25 \%$ lub $50 \%$ objętości roztworu, z którego piana została wytworzona, jest miarą trwałości piany;

- czas gaszenia - czas od chwili rozpoczęcia podawania środka gaśniczego do całkowitego ugaszenia pożaru testowego [21]. Im krótszy czas gaszenia, tym większa skuteczność gaśnicza piany.

- czas nawrotu palenia - czas zaniku piany na powierzchni cieczy pod wpływem działania ognia [21]. Im dłuższy czas nawrotu palenia, tym lepsza zdolność zabezpieczania przed ponownym zapaleniem materiału palnego.

Badania parametrów piany (liczba spienienia, szybkość wykraplania piany) oraz skuteczności gaśniczej środków gaśniczych do zastosowania $z$ wodą słoną wykonuje się z zastępczą wodą morską o następującym składzie wagowym [13-19]: chlorek sodowy $(\mathrm{NaCl})-2,50 \%$, chlorek magnezowy $\left(\mathrm{MgCl}_{2} \times 6 \mathrm{H}_{2} \mathrm{O}\right)-1,10 \%$, chlorek wapniowy $\left(\mathrm{CaCl}_{2} \times 2 \mathrm{H}_{2} \mathrm{O}\right)-0,16 \%$, siarczan sodowy $\left(\mathrm{Na}_{2} \mathrm{SO}_{4}\right)-0,40 \%$, woda wodociągowa $-95,84 \%$.

W wyżej opisanych badaniach pianę wytwarza się za pomocą prądownicy, wytwornicy lub odpowiedniego generatora. Warunki otoczenia oraz temperatury cieczy używanych podczas badań podane są w odpowiednich normach [13-19]. Ciśnienie na dyszy ustawia się w odpowiednim zakresie (dane w tabeli 1) tak, aby otrzymać wymaganą w danej metodzie szybkość przepływu strumienia piany. Badanie polega na napełnieniu naczynia pomiarowego pianą, starając się nie pozostawiać pustych przestrzeni.

Badania skuteczności gaśniczej zgodnie z PN-EN 1568 [15-16] oraz przepisami IMO [19] prowadzi się w warunkach podanych w tabeli 1 . Na rycinach $2-6$ przedstawiono przebieg testów gaśniczych wykonywanych zgodnie z tymi metodami.

Tabela 1. Parametry testu skuteczności gaszenia wg [15-16], [19]

Table 1. Test parameters for successful extinguishing of fires according to [15-16], [19]

\begin{tabular}{|c|c|c|c|}
\hline Parametr / Parameter & EN 1568-3 & EN 1568-4 & MSC.1/Circ.1312 \\
\hline $\begin{array}{l}\text { Kształt tacy/ } \\
\text { Shape of fire tray }\end{array}$ & $\bullet$ & $\bullet$ & $\mathbf{\square}$ \\
\hline $\begin{array}{l}\text { Powierzchnia tacy/ } \\
\text { Area of fire tray }\left[\mathrm{m}^{2}\right]\end{array}$ & 4.52 & 1.73 & 4.52 \\
\hline $\begin{array}{l}\text { Głębokość tacy/ } \\
\text { Depth of a fire tray [mm] }\end{array}$ & 200 & 150 & 200 \\
\hline $\begin{array}{l}\text { Powierzchnia ekranu/ } \\
\text { Area of screen [m2] }\end{array}$ & 1 & 1 & 1 \\
\hline $\begin{array}{l}\text { Ciśnienie na dyszy/ } \\
\left.\text { Nozzle pressure [bar }{ }^{4}\right]\end{array}$ & $6.3 \pm 0.3$ & $6.3 \pm 0.3$ & $6.3 \pm 0.3$ \\
\hline $\begin{array}{l}\text { Wydajność prądownicy/ } \\
\text { Flow rate }[1 / \mathrm{min}]\end{array}$ & 11.4 & 11.4 & $11.4-34.2$ \\
\hline $\begin{array}{l}\text { Rodzaj i ilość paliwa/ } \\
\text { Type and quantity of fuel }\end{array}$ & $\begin{array}{c}\text { n-heptan, } 144 \text { l na warstwie } 901 \\
\text { wody/ } \\
\text { n-heptane, } 144 \text { l on } 901 \text { layer of } \\
\text { water }\end{array}$ & $\begin{array}{l}\text { aceton/acetone, } 1251 \\
\text { izopropanol/ } \\
\text { isopropanol, } 1251\end{array}$ & $\begin{array}{l}\text { n-heptan/n-heptane, } \\
144 \text { l aceton/acetone, } \\
2341\end{array}$ \\
\hline $\begin{array}{l}\text { Rodzaj i ilość wody w tacy/ } \\
\text { Type and quantity of water in a fire tray }\end{array}$ & $\begin{array}{l}\text { wodociągowa/ } \\
\text { tap water, } 901\end{array}$ & - & morska/sea water, 901 \\
\hline
\end{tabular}

\footnotetext{
W dokumentach normatywnych ciśnienie podane jest w barach. Według układu SI ciśnienie 6,3 bar = 0,63MPa.
} 


\begin{tabular}{|c|c|c|c|}
\hline Parametr / Parameter & EN 1568-3 & EN 1568-4 & MSC.1/Circ.1312 \\
\hline $\begin{array}{l}\text { Czas rozpalenia/ } \\
\text { Kindling duration }[s]\end{array}$ & $60 \pm 2$ & $120 \pm 2$ & $60 \pm 2$ \\
\hline $\begin{array}{l}\text { Sposób podawania piany/ Method of } \\
\text { foam delivery }\end{array}$ & $\begin{array}{l}\text { bezpośrednie lub łagodne/ } \\
\text { direct or gentle }\end{array}$ & łagodne/gentle & łagodne/gentle \\
\hline $\begin{array}{l}\text { Czas podawania piany/ } \\
\text { Foam delivery duration }[\mathrm{s}]\end{array}$ & $\begin{array}{c}300 \pm 2 \text { - łagodne/gentle } \\
180 \pm 2 \text { - bezpośrednie/direct }\end{array}$ & $\begin{array}{l}180 \pm 2-\mathrm{kl} .1 / \text { class } 1 \\
300 \pm 2-\mathrm{kl} .2 / \text { class } 2\end{array}$ & $300 \pm 2$ \\
\hline $\begin{array}{l}\text { Czas gaszenia/ } \\
\text { Extinguishing duration [min] }\end{array}$ & $\begin{array}{l}\leq 5-\mathrm{kl} .3 / \text { class } 3 \\
\leq 4-\mathrm{kl} .2 / \text { class } 2 \\
\leq 3-\mathrm{kl} .1 / \text { class } 1\end{array}$ & $\begin{array}{l}\leq 5-\mathrm{kl} .2 / \text { class } 2 \\
\leq 3-\mathrm{kl} .1 / \text { class } 1\end{array}$ & $\leq 5$ \\
\hline $\begin{array}{l}\text { Wielkość naczynia do nawrotu palenia/ } \\
\text { Dimensions of burn-back container } \\
{[\mathrm{mm}]}\end{array}$ & $\begin{array}{l}\varnothing=300 \\
h=250\end{array}$ & $\begin{array}{l}\varnothing=300 \\
h=250\end{array}$ & $\begin{array}{l}\varnothing=300 \\
h=150\end{array}$ \\
\hline $\begin{array}{l}\text { Czas nawrotu palenia/ } \\
\text { Burn-back duration [min] }\end{array}$ & $\begin{array}{c}\geq 5^{*}-\text { łagodne/gentle } \\
\geq 10^{* *}-\text { bezpośrednie/direct }\end{array}$ & $\geq 5$ & $\geq 15$ \\
\hline
\end{tabular}

${ }^{*}$ w zależności od uzyskanego czasu określa się poziom odporności na nawrót palenia B, C lub D.

${ }^{*}$ uzyskanie ponad 10 min nawrotu palenia - poziom odporności na nawrót palenia $\mathrm{A}$.

Źródło: Opracowanie własne.

Source: Own elaboration.

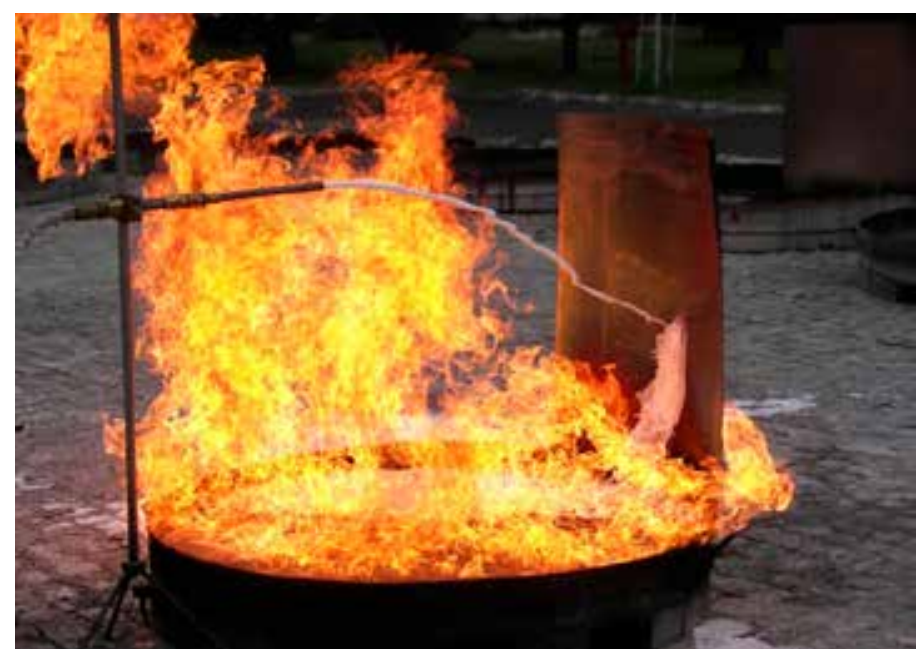

Ryc. 2. Badanie skuteczności gaśniczej pianotwórczych środków gaśniczych (podawanie łagodne) wg [15]

Fig. 2. Extinguishing effectiveness test of foam concentrates (gentle application) according to [15] Źródło: Opracowanie własne. Source: Own elaboration.

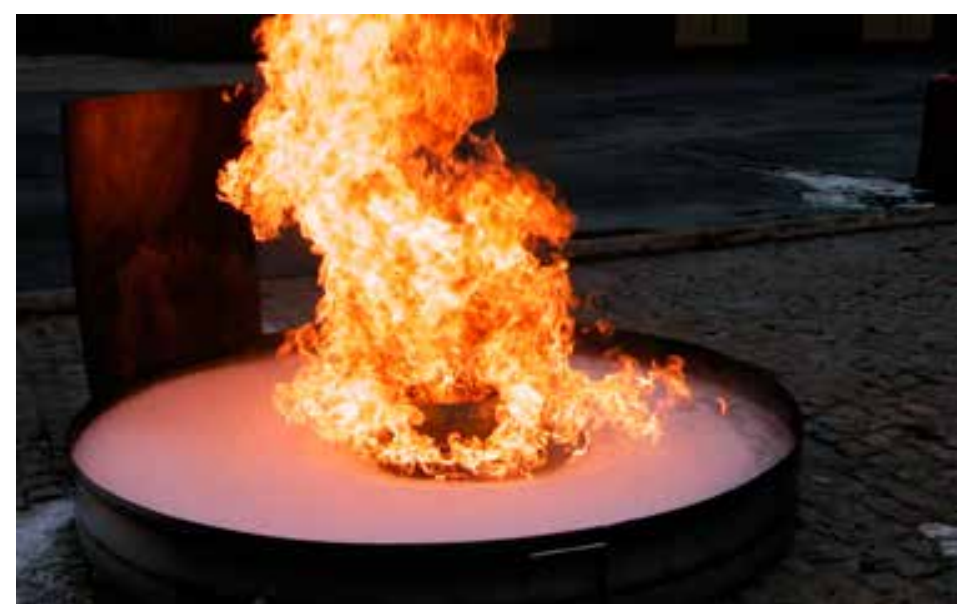

Ryc. 3. Nawrót palenia wg [15]

Fig. 3. Burn-back resistance test according to [15]

Źródło: Opracowanie własne.

Source: Own elaboration. 


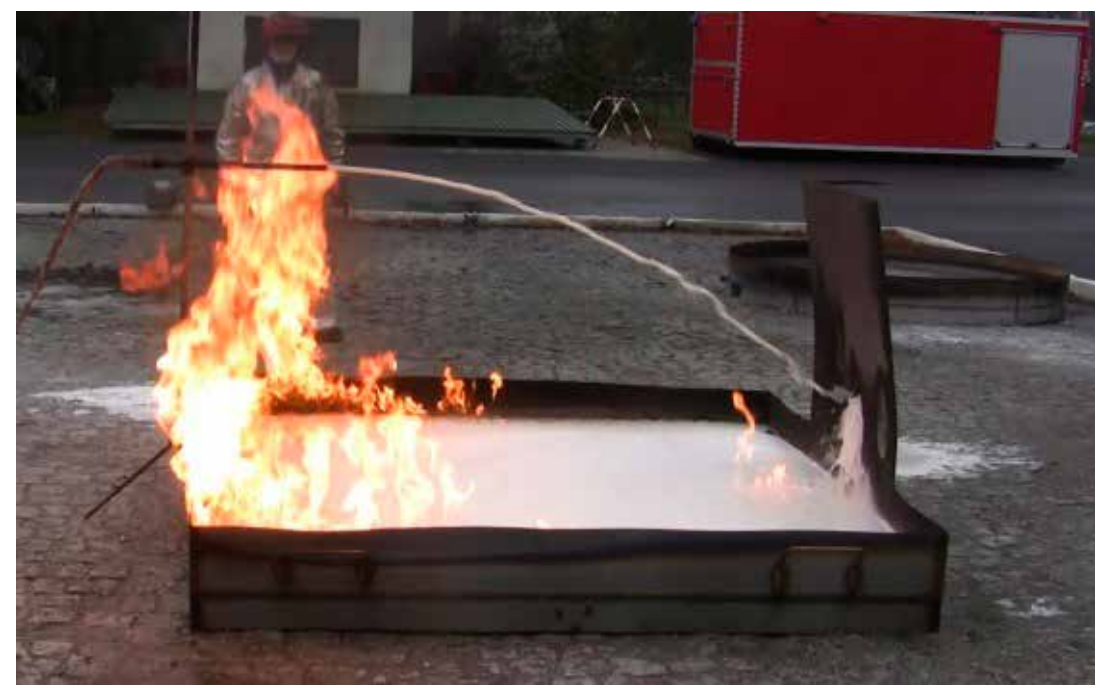

Ryc. 4. Badanie skuteczności gaśniczej wg [19]

Fig. 4. Extinguishing effectiveness test according to [19]

Źródło: Opracowanie własne.

Source: Own elaboration.

Środek pianotwórczy do stosowania $\mathrm{z}$ modą morską według norm [13-16] powinien uzyskać skuteczność gaśniczą zarówno działaniach z wodą niezasoloną, jak i morską. Natomiast według IMO [19] nie określono wymagań skuteczności gaszenia pożarów $\mathrm{z}$ użyciem wody niezasolonej.
Konieczne jest jedynie potwierdzenie właściwości gaśniczych w testach z zastosowaniem wody morskiej. Istotną różnicą między porównywanymi metodami jest dopuszczenie przez przepisy IMO stosowania do 3 prądownic (ryc. 5) równocześnie podczas wykonywania testu gaśniczego [19].



Ryc. 5. Badanie skuteczności gaśniczej wg [19] z zastosowaniem 3 prądownic

Fig. 5. Extinguishing effectiveness test according to [19] delivery with 3 nozzles Źródło: Opracowanie własne. Source: Own elaboration.

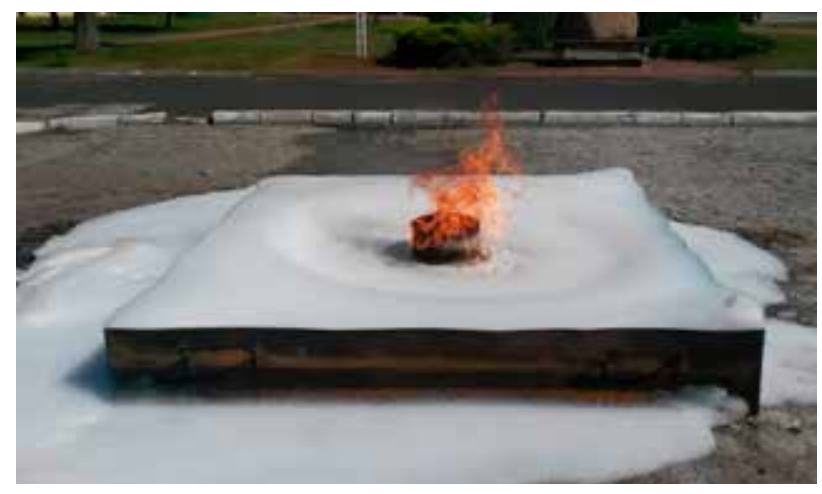

Ryc. 6. Nawrót palenia wg [19]

Fig. 6. Burn-back resistance test according to [19]

Źródło: Opracowanie własne.

Source: Own elaboration. 


\section{Materiały i metody}

W pracy przedstawiono porównanie wyników jakości piany i skuteczności gaśniczej trzech syntetycznych środków pianotwórczych (środki S1, S2 i S3) i jednego środka fluoroproteinowego (FP4). Zgodnie $\mathrm{z}$ deklaracją producenta środki S1 i S3 można stosować jedynie z wodą wodociągową niezasoloną, natomiast środki S2 i FP4 są odporne na działanie składników wody morskiej, w związku z tym pianę gaśniczą można wytwarzać zarówno przy użyciu wody wodociągowej, jak i zasolonej.

W celu wykazania różnic jakości piany wytworzonej $\mathrm{z}$ koncentratów przeznaczonych do stosowania $\mathrm{z}$ wodą niezasoloną i wodą morską wykonano badania liczby spienienia i czasu wykraplania 50\% piany wg [15-16], [19].

Wykonano badania skuteczności gaśniczej metodą wg [15] z zastosowaniem wody niezasolonej i morskiej dla syntetycznego środka gaśniczego (S3). Do badań sporządzono 3-procentowe roztwory, zgodnie z zaleceniami producenta. Przeprowadzono także testy porównawcze skuteczności gaszenia n-heptanu metodą wg [15-16] oraz [19] 6-procentowym roztworem fluoroproteinowego środka pianotwórczego (FP4) przeznaczonego do stosowania Z wodą wodociągową i morską. Test wg [19] wykonano stosując jedna prądownicę o wydajności ok. 11, 4 1/min.

\section{Wyniki i dyskusja}

Na rycinach 7 i 8 przedstawiono porównanie parametrów piany 3-procentowych roztworów syntetycznych środków pianotwórczych oraz 6-procentowego roztworu środka fluoroproteinowego sporządzonych na bazie wody śródlądowej niezasolonej oraz zastępczej wody morskiej.

Największą liczbę spienienia uzyskano dla pianotwórczego środka S2 przy zastosowaniu z wodą wodociągową, natomiast najmniejszą dla środka S1 przy stosowaniu $\mathrm{z}$ wodą morską. Duża pianotwórczość jest związana $\mathrm{z}$ większą trwałością wytworzonej piany, co potwierdzają wartości czasu wykraplania dla środków S1 oraz S2.

Wyniki badań środków przeznaczonych do stosowania $\mathrm{z}$ wodą niezasoloną oraz $\mathrm{z}$ morską potwierdziły gorszą zdolność pianotwórczą i mniejszą trwałość piany wytworzonej z koncentratów przy zastosowaniu wody zasolonej. W przypadku środków przeznaczonych do wytwarzania pian gaśniczych $\mathrm{z}$ wodą morską pogorszenie parametrów piany w stosunku do pian uzyskanych $\mathrm{z}$ roztworów na bazie wody wodociągowej było relatywnie małe (do ok. 15\%), podczas gdy dla środków nieprzeznaczonych do stosowania $\mathrm{z}$ wodą zasoloną trwałość piany zmniejszyła się o ok. 75\%. Ostateczna ocena przydatności stosowania środka $\mathrm{z}$ wodą zasoloną wymaga jednak wykonania testów gaśniczych.



Ryc. 7. Porównanie liczby spienienia środków do zastosowania z wodą wodociągową i morską

Fig. 7. Comparison of expansion ratio for foam concentrate intended for use with fresh water and sea water Źródło: Opracowanie własne.

Source: Own elaboration.

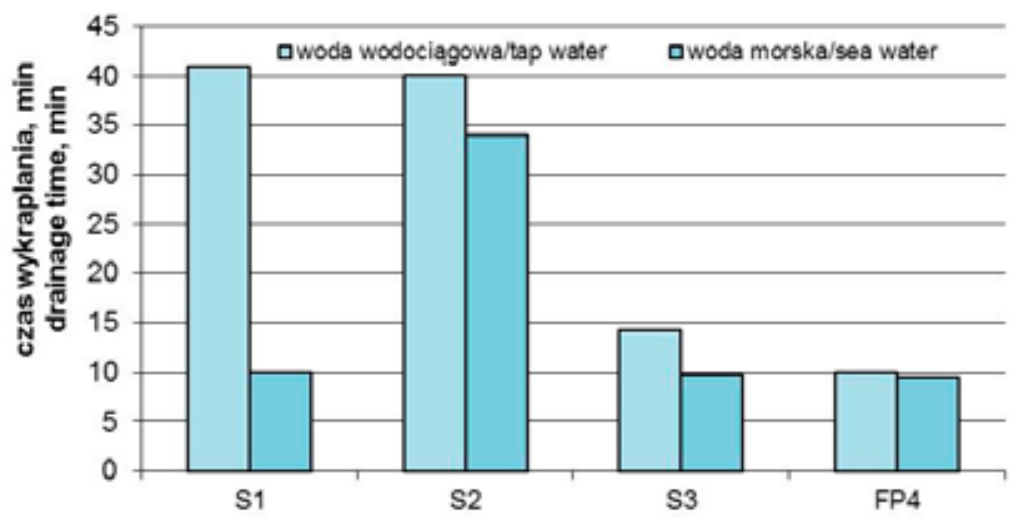

Ryc. 8. Porównanie czasu wykraplania $50 \%$ dla środków do zastosowania z wodą wodociągową i morską

Fig. 8. Comparison of $50 \%$ drainage time for foam concentrate intended for use with fresh water and sea water Źródło: Opracowanie własne.

Source: Own elaboration. 
Wyniki testów skuteczności gaśniczej z zastosowaniem wody niezasolonej i morskiej przedstawiono w tabeli 2 . Potwierdzono skuteczność gaszenia paliw węglowodorowych pianą wytworzoną ze środka S2 i wody wodociągowej. $\mathrm{W}$ teście gaśniczym $\mathrm{z}$ wodą morską nie uzyskano 90-procentowego opanowania pożaru ani całkowitego ugaszenia, mimo że środek posiada wystarczającą pianotwórczość. Jednak z powodu małej trwałości wytwarzanej piany środek S3 nie nadaje się on do zastosowania $\mathrm{z}$ wodą zasoloną.

Tabela 2. Skuteczność gaśnicza środka S3 - pożar n-heptanu wg [15]

Table 2. Firefighting effectiveness for synthetic agent S3 - n-heptane fire test according to [15]

\begin{tabular}{|c|c|c|c|}
\hline \multicolumn{2}{|c|}{$\begin{array}{l}\text { Wielkość mierzona/ } \\
\text { Parameter }\end{array}$} & \multirow{2}{*}{$\begin{array}{c}\begin{array}{c}\text { Woda niezasolona/ } \\
\text { Fresh water }\end{array} \\
0^{\prime} 55^{\prime \prime}\end{array}$} & \multirow{2}{*}{$\begin{array}{c}\begin{array}{c}\text { Woda morska/ } \\
\text { Sea water }\end{array} \\
\begin{array}{c}\text { nie uzyskano/ } \\
\text { not achieved }\end{array} \\
\end{array}$} \\
\hline \multirow{3}{*}{$\begin{array}{l}\text { Czas gaszenia/ } \\
\text { Extinguishing duration [min] }\end{array}$} & $\begin{array}{l}\text { Opanowanie w } 90 \% / \\
90 \% \text { under control }\end{array}$ & & \\
\hline & $\begin{array}{l}\text { Opanowanie w 99\%/ } \\
99 \% \text { under control }\end{array}$ & 1'50" & $\begin{array}{c}\text { nie uzyskano/ } \\
\text { not achieved }\end{array}$ \\
\hline & $\begin{array}{l}\text { Opanowanie całkowite/ } \\
\text { Completely under control }\end{array}$ & $3^{\prime} 00^{\prime \prime}$ & $\begin{array}{c}\text { nie uzyskano/ } \\
\text { not achieved }\end{array}$ \\
\hline $\begin{array}{l}\text { Czas nawrotu palenia/ } \\
\text { Burn-back duration [min] }\end{array}$ & $\begin{array}{l}25 \% \text { nawrót palenia/ } \\
25 \% \text { burn-back }\end{array}$ & $16^{\prime} 45^{\prime \prime}$ & $\begin{array}{c}\text { nie uzyskano/ } \\
\text { not achieved }\end{array}$ \\
\hline
\end{tabular}

W celu porównania skuteczności gaszenia n-heptanu metodą wg [15] oraz [19] wykonano testy gaśnicze dla fluoroproteinowego środka pianotwórczego (FP4) przeznaczonego do stosowania $\mathrm{z}$ wodą wodociągową i morską. Przykładowe wyniki przedstawiono w tabeli 3. Dla badanego środka FP4 nie uzyskano całkowitego ugaszenia pożaru testowego $\mathrm{z}$ n-heptanem $\mathrm{z}$ powodu małej odporności piany na wysoką temperaturę oraz małej zdolności do rozpływania się po powierzchni paliwa. Na skutek kontaktu z płomieniami na powierzchni piany powstawała „skorupa” zmniejszająca zdolność rozpływania się cieczy. Zaobserwowano niewystarczającą izolacyjność piany, co powodowało „przebijanie” na jej powierzchnię par powstających podczas ogrzewania n-heptanu (ryc. 9). Krótki czas nawrotu palenia prawdopodobnie był związany z brakiem całkowitego opanowania pożaru i obecnością płomieni pozostających przy krawędzi tacy.



Ryc. 9. Brak całkowitego ugaszenia pożaru testowego wg [19]

Fig. 9. Failed to completely extinguish the test fire according to [19]

Źródło: Opracowanie własne.

Source: Own elaboration.

W badaniach porównawczych potwierdzono mniejszą skuteczność gaśniczą środka pianotwórczego podczas stosowania wody morskiej. Dodatkowe utrudnienie warunków gaszenia, wynikające z przepisów [19] tj. obecność zasolonej wody pod warstwą płonącego paliwa węglowodorowego, powoduje jeszcze intensywniejsze niszczenie piany i brak całkowitego ugaszenia pożaru.

Zaobserwowano, że przy zastosowaniu takich samych wydajności piany spełnienie wymagań wg przepisów
IMO jest trudniejsze. Jednakże metoda MSC.1/Circ.1312 dopuszcza w teście skuteczności gaśniczej jednoczesne zastosowanie do trzech dysz o wydatku 11,4 1/min każda, co znacznie zwiększa efektywność działań gaśniczych. Przy zastosowaniu trzech prądownic nie tylko uzyskano całkowite ugaszenie, ale czas gaszenia pożaru testowego zmniejszył się o ok. 4 min w porównaniu z testem przeprowadzonym zgodnie z PN-EN 1568-3 [15]. 
Tabela 3. Badanie skuteczności gaszenia n-heptanu środkiem FP4 wg PN-EN 1568-3 [15] dla wody wodociągowej i morskiej, podawanie łagodne i wg przepisów IMO [19]

Table 3. N-heptane fire test for FP4 foam concentrate according to PN-EN 1568-3 [15] with fresh water and sea water, gentle application in compliance with IMO regulations [19]

\begin{tabular}{|c|c|c|c|c|c|}
\hline \multirow{3}{*}{\multicolumn{2}{|c|}{ Metoda/Method }} & \multicolumn{2}{|c|}{ PN-EN 1568-3 } & \multirow{2}{*}{\multicolumn{2}{|c|}{$\begin{array}{c}\text { IMO MSC.1/Circ. } 1312 \\
\text { woda słona/sea water }\end{array}$}} \\
\hline & & \multirow{2}{*}{$\begin{array}{c}\text { woda } \\
\text { wodociągowa/ } \\
\text { tap water }\end{array}$} & \multirow{2}{*}{$\begin{array}{l}\text { woda słona/ } \\
\text { sea water }\end{array}$} & & \\
\hline & & & & 1 prądownica/1 nozzle & $\begin{array}{l}3 \text { prądownice/ } \\
3 \text { nozzles }\end{array}$ \\
\hline \multirow{3}{*}{$\begin{array}{l}\text { Czas gaszenia/ } \\
\text { Extinguishing } \\
\text { duration [min] }\end{array}$} & $\begin{array}{l}\text { Opanowanie w 90\%/ } \\
90 \% \text { under control }\end{array}$ & 0’37”' & 0’43” & 0’33" & 0’10" \\
\hline & $\begin{array}{l}\text { Opanowanie w 99\%/ } \\
99 \% \text { under control }\end{array}$ & 1’03" & 2’19”' & $2 ’ 35^{\prime \prime}$ & $0 ’ 25^{\prime \prime}$ \\
\hline & $\begin{array}{l}\text { Opanowanie całkowite/ } \\
\text { Completely under control }\end{array}$ & 3'37' & $4 ’ 50 "$ & $\begin{array}{c}\text { nie uzyskano/ } \\
\text { not achieved }\end{array}$ & $0{ }^{\prime} 45^{\prime \prime}$ \\
\hline $\begin{array}{c}\text { Czas nawrotu } \\
\text { palenia/ } \\
\text { Burn-back } \\
\text { duration [min] }\end{array}$ & $\begin{array}{l}25 \% \text { nawrót palenia/ } \\
25 \% \text { burn-back }\end{array}$ & $13^{\prime} 35^{\prime \prime}$ & $11^{\prime} 57^{\prime \prime}$ & 9'13" & $18^{\prime} 36^{\prime \prime}$ \\
\hline
\end{tabular}

\section{Podsumowanie}

Jakość środków gaśniczych ma ogromny wpływ na efektywność działań straży pożarnej. Podczas pożarów w portach morskich szczególnie istotna jest odporność piany gaśniczej na działanie słonej wody. Długi czas gaszenia lub całkowity brak skuteczności do tłumienia płomieni oraz niebezpieczeństwo ponownego rozpalenia pożaru wykluczają możliwość stosowania takich koncentratów do wytwarzania pian gaśniczych w portach morskich. Środek gaśniczy o odpowiedniej jakości, właściwie zastosowany, zwiększa bezpieczeństwo osób oraz umożliwia ograniczenie ekonomicznych i ekologicznych strat pożarowych. Z tego powodu istotne jest odpowiednie zabezpieczenie logistyczne działań na terenie chronionego obiektu, jakim jest port morski. Jeśli środki gaśnicze stosowane są w specyficznych warunkach, np. szczególnie duże zasolenie, niska temperatura wody i powietrza, to ich jakość należy sprawdzić w takich właśnie warunkach.

Badania przedstawione w artykule wykonano w ramach działalności statutowej CNBOP-PIB (nr zadania badawczego 016/BC/CNBOP-PIB/MNiSW/2011-2016).

\section{Literatura}

[1] Notteboon T.E., Land access to sea ports, University of Antverp, Antverp 1998.

[2] Christowa C., Port morski jako centrum logistyczne w międzynarodowych łańcuchach dostaw, „Logistyka” Issue 4, 2012, pp. 53-56.

[3] Herdzik J., Analiza skutków wybranych wypadków na morzu jako zagrożeń utrudniajacych akcje ratownicze, „Logistyka” Vol. 36 Issue 4, 2014, pp. 419-429.

[4] Obolewicz A., Zagrożenia związane $z$ transportem drogowym towarów niebezpiecznych a tunele drogowe, BiTP Issue 2, 2009, pp. 97-116.

[5] Górski S., Cłapa M., Ochrona ludności w Unii Europejskiej. Podstawy prawne, sposób funkcjonowania oraz wybrane formy współpracy na poziomie unijnym, BiTP Issue 1, 2012, pp. 11-22.

[6] Mizerski A., Piany jako nośniki chemicznych środków neutralizacji skażeń, BiTP Vol. 31 Issue 1, 2013, pp. 87-93.

[7] Mazur R., Kwasiborski A., Ocena stopnia bezpieczeństwa $w$ aspekcie statystyk zdarzeń za lata 2007-2012. Pożary, BiTP Vol. 30 Issue 2, 2013, pp. 17-22

[8] Pecio M., Społeczno-ekonomiczne koszty pożarów, BiTP Vol. 35 Issue 3, 2014, pp. 39-45.

[9] Rakowska J., Porycka B., Ocena efektywności stosowania zanieczyszczonych wód powierzchniowych

w akcjach gaśniczych, CNBOP-PIB, Józefów 2012, ISBN: 978-83-61520-25-2.

[10] Schroeder M. (red.), Była taka akcja..., CNBOP-PIB, Józefów 2012, ISBN: 978-83-61520-13-9.

[11] Kamińska M., Warunki środowiskowe polskiej strefy południowego Bałtyku w 2001 roku, Materiały Oddziału Morskiego IMGW, Gdynia 2004.

[12] World Ocean Atlas 2013, [dok. elektr.] http://www.nodc. noaa.gov/OC5/woa13/ [dostęp: 10.12.2014 r.].

[13] PN-EN 1568-1:2008/AC 2010 Środki gaśnicze. Pianotwórcze środki gaśnicze. Część 1: Wymagania dotyczące środków pianotwórczych do wytwarzania piany średniej służącej do powierzchniowego gaszenia cieczy palnych nie mieszających się $\mathrm{z}$ wodą.

[14] PN-EN 1568-2:2008/AC 2010 Środki gaśnicze. Pianotwórcze środki gaśnicze. Część 2: Wymagania dotyczące środków pianotwórczych do wytwarzania piany lekkiej służącej do powierzchniowego gaszenia cieczy palnych nie mieszających się z wodą.

[15] PN-EN 1568-3:2008/AC 2010 Środki gaśnicze. Pianotwórcze środki gaśnicze. Część 3: Wymagania dotyczące środków pianotwórczych do wytwarzania piany ciężkiej służącej do powierzchniowego gaszenia cieczy palnych nie mieszających się $\mathrm{z}$ wodą. 
[16] PN-EN 1568-4:2008/AC 2010 Środki gaśnicze. Pianotwórcze środki gaśnicze. Część 4: Wymagania dotyczące środków pianotwórczych do wytwarzania piany ciężkiej służącej do powierzchniowego gaszenia cieczy palnych mieszających się $\mathrm{z}$ wodą.

[17] ISO 7203-1:2011 Fire extinguishing media. Foam concentrates. Part 1: Specification for low-expansion foam concentrates for top application to water-immiscible liquids.

[18] ISO 7203-3:2011 Fire extinguishing media. Foam concentrates. Part 3: Specification for low-expansion foam concentrates for top application to water-miscible liquids.
[19] MSC.1/Circ.1312, ed. 2009 Revised guidelines for the performance and testing criteria, and surveys of foam concentrates for fixed fire-extinguishing systems

[20] NFPA 11:2010 Standard for Low-, Medium-, and High-Expansion Foam.

[21] Rakowska J., Porycka B., Radwan K., Zastosowanie pian gaśniczych i zwilżaczy do gaszenia pożarów lasów, torfowisk i zarośli, w: Inżynieria bezpieczeństwa z zagrożenia cywilizacyjne, Zmienność zagrożeń a innowacje $w$ ratownictwie, A. Gil, U. Nowacka, M. Chmiel (red.), Centralna Szkoła Państwowej Straży Pożarniczej w Częstochowie, Częstochowa 2014, 183-202.

mł. bryg. dr inż. Joanna Rakowska - ukończyła studia na Wydziale Inżynierii Materiałowej Politechniki Warszawskiej. Stopień doktora nauk technicznych w zakresie technologii chemicznej uzyskała na Wydziale Technologii Chemicznej Politechniki Poznańskiej. Obecnie pracuje w Centrum Naukowo-Badawczym Ochrony Przeciwpożarowej - PIB w Zespole Laboratoriów Badań Chemicznych i Pożarowych. Specjalność - technologia preparatów chemicznych stosowanych przez jednostki ratowniczo-gaśnicze.

mgr Katarzyna Radwan - ukończyła studia na Wydziale Matematyczno-Przyrodniczym (kierunek chemia) Akademii Świętokrzyskiej w Kielcach. Obecnie pracuje w Centrum Naukowo-Badawczym Ochrony Przeciwpożarowej - PIB w Zespole Laboratoriów Badań Chemicznych i Pożarowych. Specjalność - technologia preparatów gaśniczych.

mgr Bożenna Porycka - ukończyła studia na Wydziale Chemii Uniwersytetu Warszawskiego. Pracuje w Centrum Naukowo-Badawczym Ochrony Przeciwpożarowej - PIB w Zespole Laboratoriów Badań Chemicznych i Pożarowych. Specjalność - technologia środków gaśniczych i neutralizujących. 